\title{
Pengasuhan Digital Keluarga Nelayan terhadap Penggunaan Smartphone pada anak usia 3-7 tahun
}

\author{
Inas Bilqis Nusaibah ${ }^{1}$, Ainin Shofiyah ${ }^{2 \bowtie}$ \\ Pendidikan Anak Usia Dini, Universitas Negeri Yogyakarta, Indonesia(1,2) \\ DOI: $\underline{10.31004 / \text { obsesi.v6i3.1797 }}$
}

\begin{abstract}
Abstrak
Penggunaan smartphone memiliki konsekuensi positif dan negatif, baik itu pada orang dewasa juga anak-anak. Tujuan penelitian ini melihat karakteristik orang tua keluarga nelayan berkaitan dengan pola-pola bimbingan atau gaya pengasuhan khusus pada anak pengguna smartphone melalui penelitian diskriptif kualitatif. Partisipan penelitian adalah sebanyak 6 keluarga nelayan yang memiliki anak usia pra-sekolah (3-7 tahun), telah diadakan wawancara terbuka dan observasi terkait aktivitas digital anak-anak mereka, respon, keyakinan, dan ketertarikan akan penggunaan smartphone sejak dini. Pada pendekatan berbasis data dan analisis data model interaktif Miles dan Huberman yang telah dilakukan, Gaya pengasuhan digital diidentifikasi memiliki kesamaan dengan gaya pengasuhan umum. Temuan penelitian lebih lanjut menunjukkan anak-anak melakukan aktivitas dengan smartphone lebih banyak jika orang tua lebih permisif dan kurang otoriter dalam melakukan pengasuhan. Implikasi pengasuhan orang tua tersebut memiliki respon yang tinggi pada pemenuhan kebutuhan anak terkait penggunaan smartphone sejak dini, namun memiliki tuntutan yang rendah terkait timbal balik atau kemungkinan dampak penggunaan smartphone.
\end{abstract}

Kata Kunci: pola asuh digital; keluarga nelayan; penggunaan smartphone usia dini.

\begin{abstract}
The use of smartphones has positive and negative consequences, both for adults and children. The purpose of this study is to look at the characteristics of fishermen's families' parents related to special guidance patterns or parenting styles for smartphone users through qualitative descriptive research. The research participants were 6 fishing families with pre-school children (3-7 years), open interviews and observations were held regarding their children's digital activities, responses, beliefs, and interest in using smartphones from an early age. In the databased approach and data analysis of Miles and Huberman's interactive model that has been carried out, digital parenting styles are identified as having similarities with general parenting styles. Further research findings show that children do more activities with smartphones if parents are more permissive and less authoritarian in their parenting. Implications of parenting is parents have a high response to meeting their children's needs related to smartphone use from an early age, but have low demands for lead. behind or the possible impact of smartphone use.
\end{abstract}

Keywords: digital parenting; fisherman's family; early age smartphone use.

Copyright (c) 2022 Inas Bilqis Nusaibah, AininShofiyah.

$\triangle$ Corresponding author:

Email Address :aeninshofiyah@gmail.com(Yogyakarta, Indonesia)

Received 9July2021, Accepted 13December 2021, Published 2 January 2022

Jurnal Obsesi : Jurnal Pendidikan Anak Usia Dini, 6(3), 2022 | 2215 


\section{PENDAHULUAN}

Anak adalah manusia dan individu dengan karakteristik khas dan unik. Karakteristik anak inilah yang membedakan individu anak dengan karakteristik orang dewasa. Anak dengan berbagai sifat seperti egosentris dan rasa ingin tahu tinggi memiliki potensi-potensi besar dalam dirinya. Hal tersebut sesuai dengan pendapat Yuliani, (2009) anak adalah manusia kecil dengan berbagai potensi yang masih terus berkembang. Berbagai potensi yang terus berkembang dalam diri anak merupakan aset berharga generasi kini dan masa depan sejalan dengan berbagai perannya sebagai individu dan bagian dari komunitas. Peran anak sebagai generasi muda dan baru diharapkan dapat membawa perubahan transformasional dalam berbagai bidang dan aspek kehidupan dengan potensi yang ia miliki. Pengembangan potensi anak tentu menjadi perhatian bersama tentang upaya yang dapat mendukung tumbuh kembang anak diberbagai aspek dan faktor. Faktor yang dapat mempengaruhi dan berkaitan dengan tumbuh kembang anak salah satunya adalah teknologi. Inovasi-inovasi yang diciptakan manusia untuk mempermudah kehidupan dapat disebut teknologi, baik itu yang sederhana, maupun kompleks dan mutakir. Sehingga, kehidupan manusia akan terus bergantung pada teknologi untuk mempermudah atau mendukung berbagai aktivitasnya, tidak terkecuali anak-anak.

Berbagai kalangan dan berbagai jenjang umur menggunakan teknologi terutama teknologi digital dan perangkatnya seperti smartphone, tablet, televisi, perangkat computer, dan lain-lain. Penggunaan perangkat digital ini pada umumnya juga disertai dengan penggunaan akses internet (Viandari dan Susilawati: 2019). Penggunaan berbagai perangkat digital dapat memicu berbagai manfaat dan dampak dalam aspek kehidupan manusia. Manusia dapat terhubung dengan lebih mudah satu sama lain tanpa adanya pertemuan langsung. Konteks negatif penggunaan smartphone dalam hubungan antar manusia berbanding terbalik dengan tujuan utama perangkat smatphone diciptakan, yaitu manusia cenderung memiliki kecenderungan kurang terhubung secara sosial, mudah teralihkan, dan tidak adanya kenikmatan komunikasi secara langsung (Dwyer, dkk: 2018).

Penggunaan smartphone, tablet dan teknologi seluler lain telah ada dan diterima secara luas dalam berbagai sendi kehidupan masa kini tidak terkecuali pada kehidupan anak-anak, khususnya yang berada pada rentang usia dini. Smartphone digunakan untuk banyak tujuan dan terus berkembang serta digunakan cenderung secara individual. Anak-anak dapat menggunakan perangkat smartphone bahkan sebelum mereka dapat mengembangkan keterampilam motorik pada tahap maksimal, karena smartphone tidak memerlukan pengontrol seperti kompoter atau perangkat game. Hal ini berakibat anak dapat menggunakan smartphone di usia semakin dini. Berdasarkan survey di Amerika Serikat (Konok et al., 2020) anak-anak menggunakan perangkat smartphone hampir satu jam untuk usia 2-4 tahun, dan kurang lebih tujuh menit untuk anak pada rentang usia kurang dari 2 tahun. Fenomena initerjadi dan sebanding seluruh dunia, tidak terkecuali Indonesia.

Hasil penelitian di Amerika menunjukkan terdapat 42,1\% dari anak-anak usia dini atau pra-sekolah yang menggunakan perangkat digital khususnya smartphone relatif tinggi, penggunaan perangkat digital tersebut pada anak prasekolah umumnya adalah menonton video atau bermain game (Rowan: 2013). Temuan penelitian menunjukkan penggunaan awal media digital sejak dini atau pra-sekolah memiliki perpektif yang terus berkembang dan berpotensi memberikan dampak positif dan negatif(Bedford, dkk: 2016). Penelitian praktis terkait adopsi penggunaan smartphoneatau perangkat digital menuntut perbaruan sesuai dengan ketegangan atau trend dan permasalahan terkini yang berkaitan di dalamnya untuk memberikan bukti yang mendukung atau menentang teori-teori berdasarkan fakta.

Berdasarkan hasil penelitian di atas, walaupun smartphonesecara pasti dapat digunakan dengan cara bermanfaaat, orang tua sering ditemui menunjukkan ketidak pastian dan keraguan tentang apa dan bagaimana cara terbaik untuk menerapkan dan mengadopsi teknologi dalam mengasuh anak di era digital. Kuppens \& Ceulemans, (2019) berpendapat bahwa walaupun pengasuhan adalah berbagai hal yang dekat dengan kehidupan 
manusiasehari-hari, namun pemahaman dan penerapannya tidak serta merta sama satu dengan lainnya serta tidak semua orang sanggup untuk konsisten di dalamnya. Jika dihubungkan pada penggunaan smartphone dalam konteks keluarga secara utuh, anak-anak mengalami kecenderungan adanya perasaan bersaing dengan smartphone demi mendapatkan perhatian orang tua mereka (Adair \& Barker 2013). Sejalan dengan penelitian tersebut Krickau et al., (2021) menyatakan penggunaan smartphone dalam konteks keluarga terutama orang tua sebagai role model dapat dikaitkan dengan perubahan dalam kepekaan dan respon orang tua pada anak-anak mereka.

Oleh karenanya penting mengetahui dan memahami bagaimana respon dan tuntutan orang tua serta pengalaman mengasuh pada perkembangan teknologi (smartphone) terhadap anak-anak mereka. Pengasuhan atau pola asuh sendiri dapat diartikan sebagai aktivitas dan upaya-upaya mendidik, membimbing, mengarahkan, atau bahkan mengontrol oleh orang tua kepada anak mereka. Casmini, (2007) menyatakan pola asuh adalah penerapan perlakuan orang tua kepada anak dalam hal mendidik, membimbing, pemberian disiplin, dan perlindungan dalam memperoleh proses kedewasaan, hingga sesuai dengan nilai-norma di masyarakat. Adapun teori-teori tentang gaya pengasuhan yang paling dikenal saat ini mengacu pada pendapat Baumrind (dalam Fathi : 2011) yaitu permisif, otoriter, dan demokratis. Pola asuh digital, mengacu dari berbagai pendapat tersebut merupakan upaya pengasuhan dan pembimbingan anak di era digital atau di era teknologi.

Kecamatan Prigi terletak di daerah tepi pantai dan pelabuhan perikanan yang aktif, sehingga mata pencarian penduduk dominan pada sektor perikanan. Keluarga nelayan yang memiliki anak dengan penggunaan smartphone sejak dini memiliki berbagai latar belakang, baik itu pendidikan dan sosial ekonomi. Temuan di lapangan menunjukkan rata-rata keluarga nelayan tersebut berlatar belakang pendidikan SMP-SMA, dengan latar belakang ekonomi menengah ke atas. Anak-anak dari keluarga nelayan tersebut ditemukan memiliki keeratan dengan teknologi utamanya smartphone. Penelitian ini diharapkan dapat memberikan gambaran terkait pengasuhan di era digital pada anak pengguna smartphone dengan latar belakang keluarga dilihat dari faktor sosial ekonomi dan pendidikan orang tuanya. Sehingga penelitian ini dilakukan dengan tujuan untuk memahami pola asuh digital yang diterapkan keluarga nelayan pada anak-anak mereka dengan rentang usia 3-7 tahun. Melihat bahwa pentingnya pemahaman tentang pola asuh yang baik dalam mendampingi, membimbing, mendidik, dan mengarahkan anak dalam penggunaan teknologi smartphone.

\section{METODOLOGI}

Penelitian ini menggunakan pendekatan dekriptif kualitatifyaitu menyelidiki kenyataan tentang permasalahan yang ada dimasyarakat. Arikunto, (2002) dan Creswell ( dalam Wiriaatmadja: 2008) pendekatan deskriptif kualitatif adalah penelitian yang mendalami atau memeriksa keadaan, kondisi, atau hal-hal yang telah diutarakan, dipaparkan dalam bentuk penelitian tentang masalah-masalah sosial dan kemanusiaan. Metode pengumpulan data menggunakan metode wawancara dan observasi di Kampung Nelayan Kecamatan Prigi, Kabupaten Trenggalek pada Juli 2021. Teknik analisis data pada penelitian ini adalah model interaktif Miles dan Huberman (Sugiyono: 2012) dengan empat langkah analisis yaitu proses pengumpulan data, reduksi data, penyajian data, dan penarikan kesimpulan. Pengumpulan data penelitin ini dilakukan secara melalui observasi, wawancara dan dokumentasi. Selanjutnya dilakukan reduksi data untuk memfokuskan pokok penelitian dan menyajikannya dalam bentuk deskriptif naratif yang sistematis, serta mengambil kesimpulan dari data penelitian yang telah dilakukan. Sampel penelitian ini adalah orang tua anak prasekolah usia 3-7 tahun terdiri dari 6 keluarga. Teknik sampling yang digunakan adalah pusposive samplingyaitu pemilihan atau pengambilan sampel/responden anggota populasi dilakukan dengan tujuan tertentu. Berikut adalah model interaktif Miles dan Huberman: 


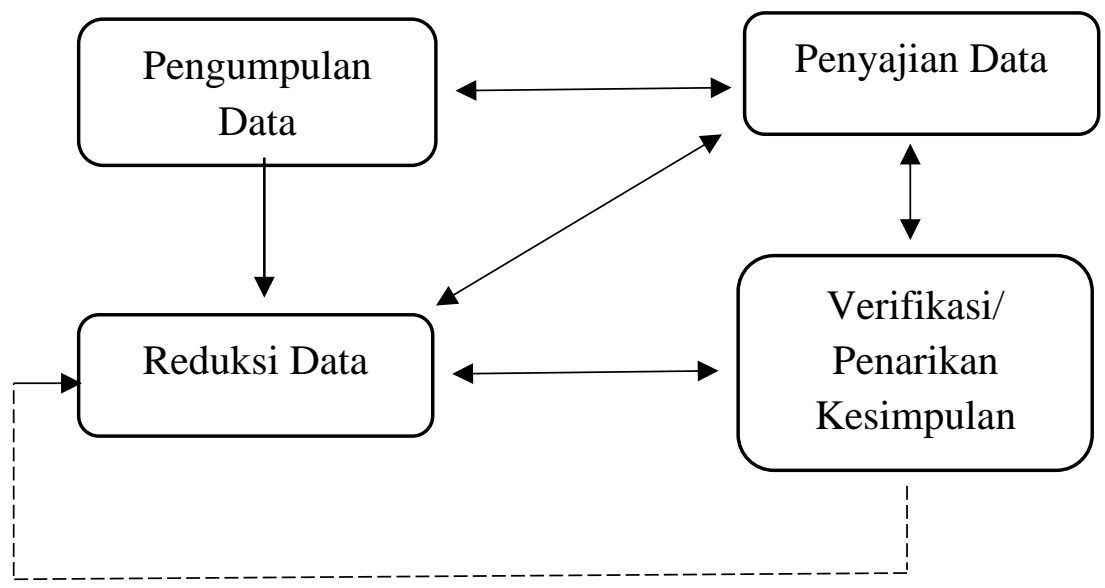

Gambar 1. Model Interaktif Miles dan Huberman

(Sugiono, 2018)

\section{HASIL DAN PEMBAHASAN}

Pola Pengasuhan Digital Keluarga Nelayan

Kondisi Sosial, ekonomi, dan pendidikan

Pada penelitian ini dilakukan pengamatan selama sepuluh hari dan wawancara dengan ayah dan ibu. Kondisi lingkungan sosial dan ekonomi diketahui bahwa warga Kampung Nelayan memiliki mata pencarian utama sebagai nelayan, namun apabila tidak musim ikan maka keluarga nelayan ini memiliki alternatif bekerja di kebun cengkeh mengingat daerah pesisir Prigi dikelilingi pegunungan. Hal ini terlihat dari kondisi ekonomi keluarga-keluarga tersebut yang terbilang berkecukupan, sehingga daya beli pada barangbarang digital cukup tinggi. Selain itu diketahui bahwa rata-rata para orang tua tersebut merupakan lulusan SMP-SMA, dengan rentang usia 25-32 tahun. Ditemukan alasan tidak melanjutkan kejenjang pendidikan yang lebih tinggi, para ayah menjawab karena harus menggantikan orang tua mereka melaut atau memelihara kapal, sehingga menganggap bahwa jenjang pendidikan tersebut sudah baik dan cukup menunjang pekerjaan mereka. Sedangkan para ibu menyebutkan bahwa tuntutan keluarga dan adanya keyakinan menikah menjadi alasan utama untuk tidak melanjutkan pendidikan. Dibuktikan dengan pernyataan subjek AF dan MS.

"Rata-rata pendapatan kalau melaut itu tergantung hasil tangkapan, kalau banyak dan harga pasar bagus ya bisa sekali melaut bisa puluhan juta, apalagi kalau pemilik kapal lebih besar dari itu. Kalau ndak melaut ya tetep bisa ada hasil dari kebun cengkeh, durian, manggis, sawah juga." (subjek $\mathrm{AF})$

"Kebanyakan bapak-bapak disini ya SMP-SMA mbak. Paling ya kalau dikira-kira 60 \% jadi nelayan nerusin kerja orang tuanya, sisanya ya ada yang melanjutkan sekolah dan ada juga yang merantau keluar daerah. Wong ya wis cukup buat ngopeni kapal dan keluarga. Kalau ibu-ibu ya kebanyakan karena sudah ada calon, ndak usah suwi-suwi dinikahkan saja."(subjek MS)

Beberapa orang tua menganggap bahwa pendidikan sebagai nelayan tidak perlu terlalu tinggi, karena ilmu mengatur dan mengelola kapal dipelajari secara turun temurun dari generasi sebelumnya melalui praktek langsung. Namun, keluarga-keluarga tersebut menyebutkan bahwa pendidikan tetap penting. Apabila situasi dan kondisi keluarga memungkinkan untuk melanjutkan pendidikan, mereka tidak memungkiri cita-cita untuk melanjutkan pendidikan ke tingkatan yang lebih tinggi, sehingga memiliki wawasan dan perekonomian lebih baik. 


\section{Pemahaman Pengasuhan Di Era Digital dan Penggunaan Smartphone pada Anak}

Hasil penelitian yang dilaksanakan diKampung Nelayan Kecamatan Prigi berkaitan dengan pola asuh digital keluarga nelayan terhadap penggunaan smartphone anak usia 3-7 tahun, diketahui respondan tuntutan orang tua pada anak-anak mereka menunjukkan gaya pengasuhan yang diterapkan. Gaya pengasuhan digital diidentifikasi memiliki kesamaan dengan gaya pengasuhan umum.Baumrind dalam (Respati et al., 2006)orang tua memiliki dimensi dasar dalam pengasuhan yaitu respon dan tuntutan. Penggambaran respon orang tua pada anak diasosiasikan dengan pemberian afeksi atau kehangatan, perhatian dan dukungan secara fisik serta emosional. Hal ini terlihat dari wawancara dan observasi pada subjek penelitian ketika peneliti memberikan pertanyaan terkait harapan dan tuntutan penggunaan smartphone pada anak.

"HP itu saya ndak ngasih langsung. Awalnya dia lihat saya pegang, terus sudah bisa main, ya saya belikan saja biar tidak pakai punya orang tuanya. Harapannya kan banyak pelajaran lewat HP sekarang, jadi sekalian anak belajar"(subjek KM)

"Saya kalau momong itu lebih ringan kalau ada HP, anak ndak rewel. Anak bisa belajar juga, dia taunya bahasa inggris ya dari HP itu, banyak manfaatnya" (subjek JT)

Orang tua meyakini bahwa penggunaan smartphone memiliki banyak manfaat pada anak-anak mereka. Diketahui melalui observasi, orang tua beberapa kali melihat konten yang diakses anak sebagai bentuk pengawasan dan respon. Namun, pengawasan dan tata cara mengoperasikan perangkat smartphone tidak secara terang-terangan diajarkan, anak meniru perilaku penggunaan smartphone dari orang tuanya. Orang tua perlu memahami secara lebih khusus terkait pengasuhan dan pola penggunaan smatphone pada anak (Park, 2020). Hal ini mengarah pada anak tidak hanya meniru perilaku penggunaan smartphone orang tua namun, orang tua dapat secara aktif berperan mengarahkan dan mendisiplinkan penggunaan smartphone. Temuan penelitian lebih lanjut menunjukkan anak-anak melakukan aktivitas dengan smartphone lebih banyak jika orang tua lebih permisif dan kurang otoriter dalam melakukan pengasuhan. Lebih permisif ini diartikan orang tua memiliki respon yang tinggi pada pemenuhan kebutuhan anak terkait penggunaan smartphone sejak dini, seperti ditemukan pada namun memiliki tuntutan yang rendah terkait timbal balik atau kemungkinan dampak penggunaan smartphone.

"Saya agak khawatir sebenarnya kalau dia main HP terus, tapi kok dia bisa belajar nyanyian baru, bahasa baru ya lewat HP. Jadi selama ndak liat yang macem-macem saya bolehin main." (subjek NB)

"Saya kan repot mbak ngurus dapur, suami juga kerja. Daripada anaknya rewel terus griduni, saya kasih yo*tube biar dia nonton video saja. Ayahnya juga ndak melarang, nanti paling diingatkan kalau waktu maem dan waktu tidur diambil HPnya. Kadang malah main HP sendiri-sendiri mereka, saya yang negur" (subjek SA)

Penggambaran tersebut mengacu pada observasi beberapa aspek penggunaan smartphone. semakin positif sikap orang tua terhadap penggunaan smartphone dini, semakin banyak waktu yang dihabiskan anak untuk melakukan penggunaan tersebut. Hasil wawancara dan temuan penelitian ini konsisten terhadaphasil temuan penelitian sebelumnya yang menunjukkan bahwa sikap positif terhadap media terkait dengan tingkat konsumsi media anak yang lebih tinggi(Cingel \& Krcmar, 2013). Sikap orang tua mungkin dipengaruhi pada keyakinan tentang manfaat potensial dan bahaya penggunaan smartphone di usia awal. Namun temuan penelitian ini bertentangan dengan hasil dari Pempek \& McDaniel, (2016), jumlah penggunaan seluler orang tua tidak berpengaruh, tetapi tingkat keterikatan smartphone orang tua berkaitan dengan jumlah penggunaan smartphone anak.

Hal ini dikarenakan tidak hanya melalui perilaku keterikatan tetapi juga melalui sikap, respon dan emosi orang tua dapat menjadi teladan bagi anak mereka. Penggunaan sistem operasi smartphone tertentu seperti Android atau iOS didukung pada persepsi orang tua 
terkait kefektifan dan dampak penggunaan yang cenderung berbanding sama, baik itu persepsi positif dan negati. Orangtua dengan keterikatan pada perangkat smartphone yang lebih tinggi dapat berkontribusi pada anak-anak dalam mengembangkan sikap positif terhadap perangkat digital dan karena orang tua mereka juga cenderung penggunaan perangkat smartphone, mengakibatkan anak-anak yang lebih sering menggunakannya. Dari perspektif lain, orang tua yang sangat terlibat secara emosional dengan media digital memiliki respon dan tuntutan yang kurang untuk berinteraksi dengan anak mereka, sehingga anak melibatkan dirinya sendiri melalui beberapa cara lain, misalnya terlihat dari observasi dan wawancara orang tua yang sibuk, ayah bekerja dan ibu dengan pekerjaan domestik mewakilkan waktu mereka dengan anak menggunakan smartphone agar anak tidak rewel dan menganggu pekerjaan.

Penemuan penelitian selanjutnya terkait pengasuhan orang tua yang lebih permisif tersebut adalah adanya perubahan interaksi orang tua dan anak pada penggunaan smartphone berkala atau secara terus menerus pada jenjang waktu tertentu. Dibuktikan melalui hasil pengamatan dan wawancara orang tua.

"Anak itu sering lebih suka dolanan sama HPnya kalau di rumah. Nanti mau lepas dari HP kalau lapar atau minta jajan. Jarang saya itu main apa gitu sama anak, dia demennya HP. Asal ndak rewel." (subjek WP) (subjek TY)

"Ya mainnya pake HP, main game sama anak. Anaknya suka, saya juga bisa lebih akrab"

Berdasarkan hal tersebut, interaksi orang tua dan anak pra-sekolah mengalami perubahan. Perubahan ini terjadi pada setiap aktifitas antara orang tua dan anak terdapat keterlibatan penggunaan smartphone di dalamnya. Orang tua menenangkan dan mengusahakan untuk lebih dekat pada anak-anak mereka dengan perantara smartphone. Hal ini berasosiasi dengan temuan penelitian sebelumnya yang menunjukkan hasil bahwa penggunaan smartphone sedini ini memiliki potensi manfaat untuk mendukung pengasuhan(Mangan et al., 2018). Manfaat ini lebih banyak ditemukan pada pola permisif dan hanya sedikit pada pola otoritatif dan otoriter(Knitter \& Zemp, 2020). Pendapat tersebut sejalan dengan hasil temuan pengasuhan keluarga nelayan yang lebih permisif terkait penggunaan smartphone pada anak-anak mereka. Perubahan interaksi dengan melibatkan penggunaan smartphone dipandang orang tua sebagai hal yang baik, walaupun sebelumnya mereka menyatakan kekhawatiran pada penggunaan smartphone. Hal ini perlu diteliti lebih lanjut terkait konsistensi paradigma penggunaan smartphone pada keluarga nelayan tersebut.

"Saya ini sebagai bapak kan ya harus kerja, istri di rumah Mbak. Saya sendiri lulusan SMA, istri SMP. Kalau ndak melaut ya saya bikin jaring ikan, kadang ndak bisa ikut momong anak, istri juga pasti ada repotnya. Jadi kalau lewat HP bisa ngajarin anak, kan banyak aplikasi yang buat belajar itu. Ya walaupun kami kasarannya ndak sekolah tinggi, lewat HP itu bisalah ngajarin, disambi kerjaan. Apalagi banyak sekarang HP murah kualitasnya juga bagus, buat anak." (Subjek AF)

"Kalau saya itu bingung Mbak mau mulai ngajarin misal berhitung, membaca itu dari mana. Ya paling gampang ada aplikasi di HP itu membantu sekali. Apalagi bisa sambil ngerjakan yang lain. Tetep saya awasi kalau sudah kelamaan itu, tapi ya kadang anaknya nangis, saya kasih lagi Hpnya. Saya inikan ndak tau Mbak ukuran ngajarin anak itu gimana, wong ya masih kecil sudah dimantu." (Subjek SA)

Ditemukan pula bahwa orang tua lebih permisif atau memberikan keleluasaan pada anak karena faktor pendidikan yang lumayan rendah yaitu lulusan SMP-SMA atau ada pula yang putus sekolah, sehingga penggunaan smartphone pada anak sejak dini menimbulkan rasa bangga dan ketertarikan lebih besar, serta sangat minimal mengaitkannya dengan dampak kerusakan atau dampak negatif pada anak. (Meng et al., 2020) minimalnya orang tua mengaitkan dengan dampak negatif disebabkan manfaat mediasi dengan anak melalui sarana smartphone dan berbagai aktifitas yang dapat dilakukan melaluinya. Terkait dengan usia orang 
tua memberikan perangkat digital pada anak sejalan dengan temuan dan wawancara di atas, yaitu pada rentang usia 3-7 tahun. Orang tua menemukan anak dapat mengoperasikan perangkat tanpa diajari, sehingga hal ini mendukung keyakinan orang tua pada dampak positif penggunaan smartphone sejak dini. Sejalan dengan penelitian ini, hasil penelitian Konok et al., (2020) bahwa anak-anak mulai menggunakan perangkat digital pada usia-usia awaldaripada penelitian dan kasus sebelumnya (anak dengan rentang usia lebih tua cenderung tidak menggunakan perangkat digital sebelum usia 3 tahun dibandingkan anakanak yang lebih muda). Suasana pelaksanaan observasi dan wawancara dapat dilihat pada gambar 2.

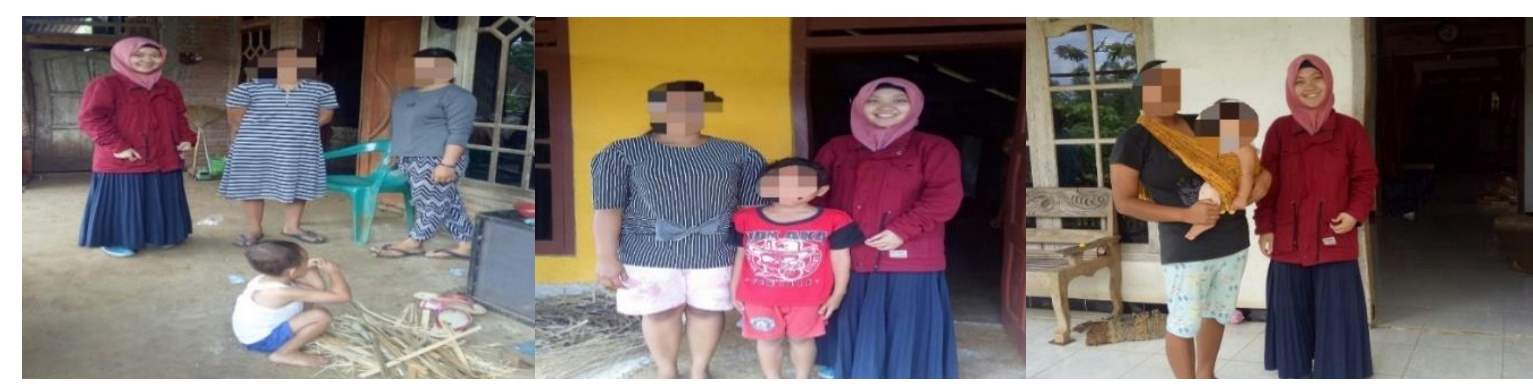

\section{Gambar 2. Observasi dan wawancara penelitian Sumber : dokumen pribadi}

\section{SIMPULAN}

Orang tua adalah pihak yang ikut serta dan berperan melalui contoh atau perilaku pemodelan, respon, tuntutan, sikap, dan keyakinan anak-anak dalam menggunakan perangkat digital khususnya smartphone sejak dini. Penggunaan smartphone sejak dini selama penelitian dua minggu di Kampung Nelayan, menunjukkan adanya kemungkinan peningkatan ditahun-tahun yang akan datang, sehingga besar kemungkinan bahwa anakanak akan menghabiskan waktunya lebih banyak pada smartphone dibandingkan dengan mainan atau kegiatan lain dalam tumbuh kembangnya.Berdasarkan hal tersebut,orang tua yang cenderung lebih permisif perlu mengantisipasi dampak secara berkelanjutan, baik itu positif maupun negatif melalui panduan penggunaan perangkat digital sesuai standar. Perlu adanya penelitian lanjutan untuk melihat secara berkelanjutan dari tahun ke tahun pada anak usia dini serta dampak yang mungkin muncul sebagai hasil penggunaan smartphone.

\section{UCAPAN TERIMAKASIH}

Puji sykur kami panjatkan kepada Allah SWT atas kemudahan dalam penulisan artikel ini. Ucapan terimakasih juga disampaikan kepada seluruh partisispan dalam penelitian ini. Besar harapan kami semoga penelitian ini dapat memberi manfaat bagi institusi dan masyarakat luas.

\section{DAFTAR PUSTAKA}

Adair, B. (2013). The Big Disconnect: Protecting Childhood And Family Relationships In The Digital Age. Harper Business.

Arikunto Suharsimi. (2002). Prosedur Penelitian. PT. Ranike Cipta.

Bedford, R., Saez de Urabain, I. R., Celeste, C. H., Karmiloff-Smith, A., \& Smith, T. J. (2016). Toddlers' fine motor milestone achievement is associated with early touchscreen $\begin{array}{llll}\text { scrolling. Frontiers in } & \text { Psychology, }\end{array}$ https://doi.org/10.3389/fpsyg.2016.01108

Braune-Krickau, K., Schneebeli, L., Pehlke-Milde, J., Gemperle, M., Koch, R., \& von Wyl, A. (2021). Smartphones in the nursery: Parental smartphone use and parental sensitivity 
and responsiveness within parent-child interaction in early childhood (0-5 years): A scoping review. Infant Mental Health Journal, 42(2), 161-175. https:// doi.org/10.1002/imhj.21908

Bunda Fathi. (2011). Mendidik Anak Dengan Al-Quran Sejak Janin. Pustaka Oasis.

Casmini. (2007). Emotional Parenting. P_Idea.

Cingel, D. P., \& Krcmar, M. (2013). Predicting Media Use in Very Young Children: The Role of Demographics and Parent Attitudes. Communication Studies, 64(4), 374-394. https:// doi.org/10.1080/10510974.2013.770408

Dwyer, R. J., Kushlev, K., \& Dunn, E. W. (2018). Smartphone use undermines enjoyment of face-to-face social interactions. Journal of Experimental Social Psychology, 78(April 2018), 233-239. https://doi.org/10.1016/j.jesp.2017.10.007

Knitter, B., \& Zemp, M. (2020). Digital Family Life: A Systematic Review of the Impact of Parental Smartphone Use on Parent-Child Interactions. Digital Psychology, 1(1), 29-43. https://doi.org/10.24989/dp.v1i1.1809

Konok, V., Bunford, N., \& Miklósi, Á. (2020). Associations between child mobile use and digital parenting style in Hungarian families. Journal of Children and Media, 14(1), 91109. https:// doi.org/10.1080/17482798.2019.1684332

Kuppens, S., \& Ceulemans, E. (2019). Parenting Styles: A Closer Look at a Well-Known Concept. Journal of Child and Family Studies, 28(1), 168-181. https:// doi.org/10.1007/s10826-018-1242-x

Mangan, E., Leavy, J. E., \& Jancey, J. (2018). Mobile device use when caring for children 0-5 years: A naturalistic playground study. Health Promotion Journal of Australia, 29(3), 337-343. https://doi.org/10.1002/hpja.38

Meng, H., Cao, H., Hao, R., Zhou, N., Liang, Y., Wu, L., Jiang, L., Ma, R., Li, B., Deng, L., Lin, Z., Lin, X., \& Zhang, J. (2020). Smartphone use motivation and problematic smartphone use in a national representative sample of Chinese adolescents: The mediating roles of smartphone use time for various activities. Journal of Behavioral Addictions, 9(1), 163174. https:// doi.org/10.1556/2006.2020.00004

Park, J. H. (2020). Smartphone use patterns of smartphone-dependent children. Child Health Nursing Research, 26(1), 47-54. https:// doi.org/10.4094/chnr.2020.26.1.47

Pempek, T. A., \& McDaniel, B. T. (2016). Young Children's Tablet Use and Associations with Maternal Well-Being. Journal of Child and Family Studies, 25(8), 2636-2647. https:// doi.org/10.1007/s10826-016-0413-x

Respati, W. ., Yulianto, A., \& Widian, N. (2006). Perbedaan Konsep Diri Antara Remaja Akhir Yang Mempersepsi Pola Asuh Orang Tua. Psikologi, 4(2), 1-20. https:/ / doi.org/10.6084/m9.figshare.9942455.v1

Rowan, C. (2013). The impact of technology on child sensory and motor development. Retrieved March, 10(8), 2017.

Sugiono. (2018). Metode Penelitian Kuantitatif, Kualitatif, dan R\&D. Alfabeta.

Sugiyono. (2012). Metode Penelitian Kuantitatif Kualitatif dan R\&D. Alfabeta.

Viandari, K. D., \& Susilawati, K. P. A. (2019). Peran pola asuh orangtua dan penggunaan gadget terhadap interaksi sosial anak prasekolah. Jurnal Psikologi Udayana, 6(01), 76. https:// doi.org/10.24843/JPU.2019.v06.i01.p08

Wiriaatmadja, R. (2008). Metode Penelitian Tindakan Kelas. PT Remaja Rosdakarya.

Yuliani, S. (2009). Konsep Dasar Pendidikan Anak Usia Dini. PT Indeks. 